\title{
Infective endocarditis with a bicuspid aortic valve and ventricular septal defect as a complication
}

\section{Petra Angebrandt* Dejan Došen, Vojtjeh Brida, Vlatka Rešković Lukšić, \\ Daniel Lovrić, Jadranka Šeparović Hanževački, Eduard Margetić}

University of Zagreb School of Medicine, University Hospital Centre Zagreb, Zagreb,

Croatia

\begin{abstract}
KEYWORDS: endocarditis, bicuspid valve, ventricular septal defect, surgery. CITATION: Cardiol Croat. 2017;12(4):127. | https://doi.org/10.15836/ccar2017.127
\end{abstract}

*ADDRESS FOR CORRESPONDENCE: Petra Angebrandt, Klinički bolnički centar Zagreb, Kišpatićeva 12, HR-10000 Zagreb, Croatia. / Phone: +385-91-159-6814 / E-mail: petraang37@yahoo.com

ORCID: Petra Angebrandt, http://orcid.org/0000-0001-5431-9736 • Dejan Došen, http://orcid.org/0000-0002-2641-4768 Vlatka Rešković Lukšić, http://orcid.org/0000-0002-4721-3236 • Daniel Lovrić, http://orcid.org/0000-0002-5052-6559 Jadranka Šeparović Hanževački, http://orcid.org/0000-0002-3437-6407 • Eduard Margetić, http://orcid.org/0000-0001-9224-363X IIIIIIIIIIIIIIIIIIIIIIIIIIIIIIIIIIIIIIIIIIIIIIIIIIIIIIIIIIIIIIIIIIIIIIIIIIIIIIIIIIIIIIIIIIIIIIIIIIIIIIIIIIIIIIIIII Introduction: Approximately three-fourths of patients with infective endocarditis have a preexisting structural cardiac abnormality at the time of the endocarditis development. Congenital heart lesions predisposing to infective endocarditis include aortic stenosis, bicuspid aortic valve, pulmonary stenosis, ventricular septal defect, patent ductus arteriosus, coarctation of the aorta, and tetralogy of Fallot. Complications of the infective endocarditis include cardiac, neurologic, renal, and musculoskeletal complications, as well as complications related to systemic infection. Cardiac complications are most common and they include: heart failure, perivalvular abscess, pericarditis, intracardiac fistula with myocardial perforation or aortic dissection. Management of patients with infective endocarditis includes antibiotic therapy as well as surgical treatment whenever it is indicated..$^{1-3}$

Case report: We present a case report of a case report of a 29 -year-old patient with congenital bicuspid aortic valve. Prior to the development of endocarditis the patient underwent a dental procedure without antibiotic prophylaxis. After couple of days he was hospitalized due to clinically signs of sepsis and infective endocarditis was reveled on echocardiography. Patient was treated with antibiotics but due to uncontrolled sepsis and severe aortic stenosis in a bicuspid aortic valve, signs of heart failure developed and patient underwent urgent cardiac surgery where the reconstruction of aortic annulus with bovine pericardium and mechanical aortic valve replacement was done. After surgery despite appropriate antibiotic therapy patient had continuous fever and clinical and laboratory signs of sepsis, so we suspected that abscess was formed. Due to that we performed 3D transesophageal echocardiography which revealed infective endocarditis vegetations on mechanical aortic valve, (Figure 1) paravalvular abscess, ventricular septal defect with significant left to right shunt and instability of mechanical valve, by itself, due to big abscess hole. (Figure 2, Figure 3). After that second cardiac surgery was performed where replacement of mechani-

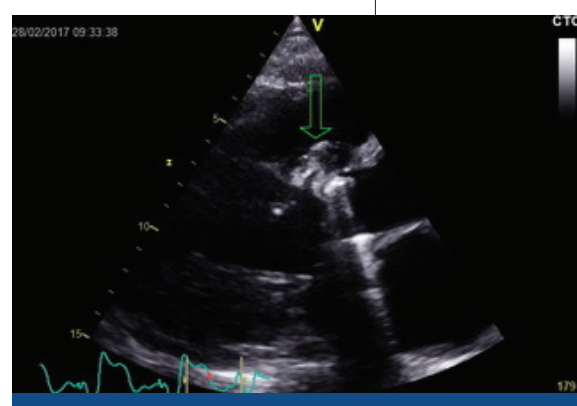

FIGURE 1. Long parasternal axis view of paravalvular abscess.
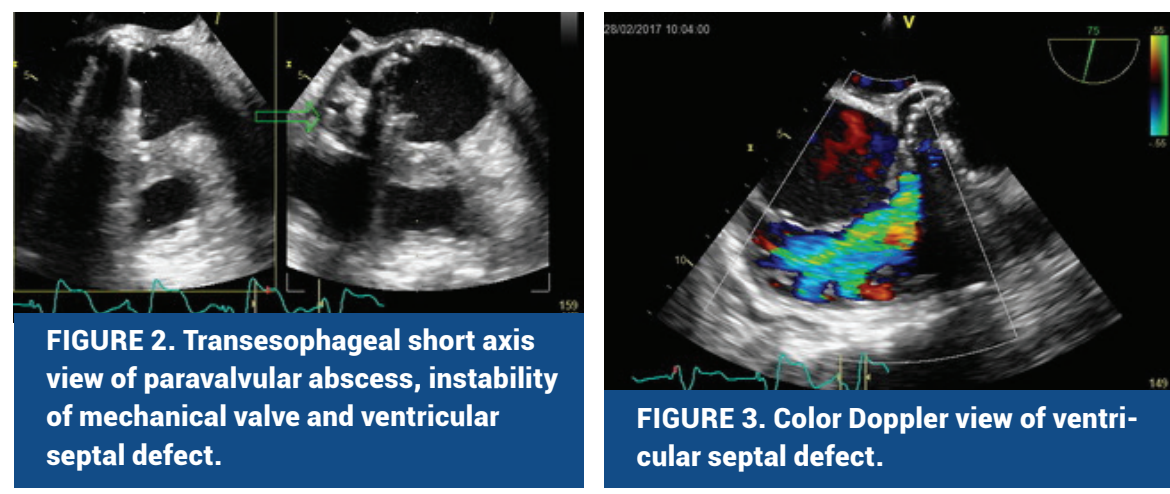

FIGURE 3. Color Doppler view of ventricular septal defect.

\section{RECEIVED:}

March 11, 2017

ACCEPTED:

April 6, 2017

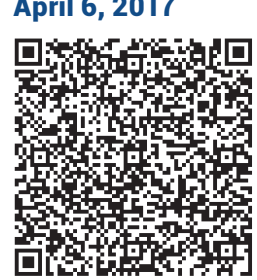

cal aortic valve with homograft was done, together with surgical repair of ventricular septal defect. After surgery transesophageal echocardiography showed normal function of replaced aortic valve, with mild regurgitation, no signs of infective endocarditis vegetations and without ventricular septal defect.

Conclusion: Perivalvular abscess should be suspected in the setting of fever despite appropriate antimicrobial therapy. Transesophageal echocardiography is more sensitive for detection of myocardial abscess than transthoracic echocardiography.

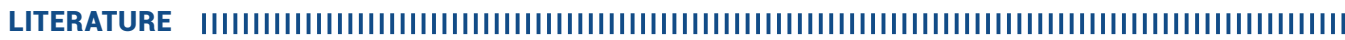

1. Pant S, Patel NJ, Deshmukh A, Golwala H, Patel N, Badheka A, et al. Trends in infective endocarditis incidence, microbiology, and valve replacement in the United States from 2000 to 2011. J Am Coll Cardiol. 2015 May 19;65(19):2070-6. https://doi.org/10.1016/j.jacc.2015.03.518

2. Tleyjeh IM, Abdel-Latif A, Rahbi H, Scott CG, Bailey KR, Steckelberg JM, et al. A systematic review of population-based studies of infective endocarditis. Chest. 2007 Sep;132(3):1025-35. https://doi.org/10.1378/chest.06-2048

3. Mansur AJ, Grinberg M, da Luz PL, Bellotti G. The complications of infective endocarditis. A reappraisal in the 1980s. Arch Intern Med. 1992 Dec;152(12):2428-32. https://doi.org/10.1001/archinte.1992.00400240050008 